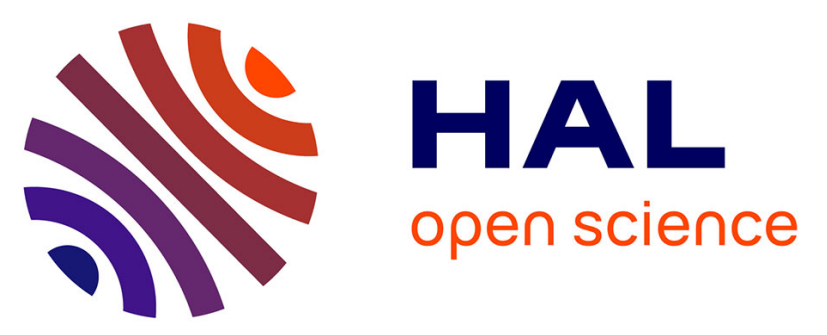

\title{
Is adaptation to climate change threatening forest biodiversity? A comparative and interdisciplinary study case of two French forests
}

Timothée Fouqueray, Antoine Charpentier, Michel Trommetter, Nathalie Frascaria-Lacoste

\section{To cite this version:}

Timothée Fouqueray, Antoine Charpentier, Michel Trommetter, Nathalie Frascaria-Lacoste. Is adaptation to climate change threatening forest biodiversity? A comparative and interdisciplinary study case of two French forests. Walter Leal Filho; Jelena Barbir; Richard Preziosi. Handbook of Climate Change and Biodiversity, Springer, pp.337-354, 2019, Climate Change Management, 978-3-319-986807. 10.1007/978-3-319-98681-4_21. hal-02456994

\section{HAL Id: hal-02456994 https://hal.science/hal-02456994}

Submitted on 27 Jan 2020

HAL is a multi-disciplinary open access archive for the deposit and dissemination of scientific research documents, whether they are published or not. The documents may come from teaching and research institutions in France or abroad, or from public or private research centers.
L'archive ouverte pluridisciplinaire HAL, est destinée au dépôt et à la diffusion de documents scientifiques de niveau recherche, publiés ou non, émanant des établissements d'enseignement et de recherche français ou étrangers, des laboratoires publics ou privés. 
Title : Is adaptation to climate change threatening forest biodiversity? A comparative and interdisciplinary study case of two French forests

Short title : Is adaptation threatening forest biodiversity?

Authors : Timothée Fouqueray ${ }^{1} *$, Antoine Charpentier ${ }^{2}$, Michel Trommetter $^{3}$ and Nathalie Frascaria-Lacoste ${ }^{1}$

${ }^{1}$ Ecologie, Systématique, Evolution, AgroParisTech, CNRS, Univ. Paris-Sud, Université Paris-Saclay, 91400, Orsay, France

${ }^{2}$ Master Bioterre, Université Paris 1 Panthéon Sorbonne, 75005 Paris

${ }^{3}$ GAEL, INRA, CNRS, Grenoble INP, Univ. Grenoble Alpes, 38000, Grenoble, France

* Corresponding author : timothee.fouqueray@agroparistech.fr

Abstract: France is highly covered by forests, upon which rely numerous jobs and natural habitats. Therefore, the country adopted a strategy of adaptation to climate change, leaning on a rich silviculture history to offer foresters various means to adapt (rotation shortening, species mixes, ...). Still, different adaptations can be interesting in a given forest, depending on the trade-off between ecosystem services: timber production, biodiversity conservation, water quality preservation, ... Hence, how do French foresters decide of the adaptation to implement? What are the impacts of their choices on biodiversity?

The following explores how adaptation in the field occurs - a complementary approach of providing better understanding of the impacts of climate change on forest biodiversity. It analyses how biodiversity is included in field adaptations, and how this concords with guidelines of sustainable forestry. Results come from semi-structured interviews led in two French forests differing in anthropization, making use of ecology and geographic sciences. The analysis discriminates two non-exclusive positions on biodiversity: "utilitarists" adapting thanks to biodiversity and "conservationists" adapting for biodiversity. Utilitarists rely on species selection or introduction of allochtonous species to resist windstorms or biological attacks for instance, a potential threat for local populations. On the opposite, conservationists favor Darwinian adaptation over interventionist strategies. Conservationists would for example prioritize spontaneous evolution, at the risk of tree species running short of time because of the speed of climate change.

These results are integrated in a wider project including natural parks managers for decision-taking in forest management.

Keywords: Adaptation, forests, biodiversity, France, social-ecological

\section{Introduction: Adaptation to climate change in multifunctional forests}

French forests are Europe's fourth biggest forests $\left(165,000 \mathrm{~km}^{2}\right)$, most of them being deciduous (MAAF 2017). Integrating biodiversity conservation in adaptation to climate change (ACC) policies is of highest importance, because of the ecological interest of forest environments and because of a French customary tradition of multifunctionality of public forests. More than just a state of mind, forest multifunctionality is legally embedded and states that public forests must simultaneously serve for various ecosystem services such as timber production, recreational activities and biodiversity conservation (Barthod 2015). This very peculiar context goes with a legacy of systemic public forest management and monitoring inherited from the sixteenth century. The necessity to integrate biodiversity 
conservation along with other forest ecosystem services is one of French characteristics that is of high interest because such constraints are commonly shared in a wide variety of situations.

Yet, even if the French government launched ACC policies and funded research programs, a knowledge gap persists concerning actual measures taken in the field. Better documentation of what really occurs in French forests is therefore needed to avoid putative maladaptation for forest biodiversity (Juhola et al. 2016). The rationale of this paper is therefore to explore what foresters actually do in the field to adapt, and more precisely how biodiversity is included in field adaptations. Maladaptation could indeed arise from utilitarian adaptations, when adapting thanks to biodiversity remains blind to Darwinian evolution (varietal selection ignoring climatic uncertainties, introduction of productive but invasive tree species, ...). Additional issues might also stem from a conservationist strategy of adapting for biodiversity, with potential prioritization of spontaneous evolution regardless of the time lag between tree Darwinian evolution and the speed of climate change (Corlett and Westcott 2013). Getting insights on how foresters behave when confronted to climate changes is key to develop accurate incentives in public policies. This paper could be of particular interest for informing both the 2018 renewal of France 4-years Mitigation Strategy and National Plan for Adaptation to Climate Change.

In the end, how do French foresters decide of the adaptation to implement? What are the impacts of their choices on biodiversity? In order to examine these issues, results from a field study depict how foresters consider biodiversity in their adaptations to climate change. We analyzed the collected mentions of ACC in the light of a few management principles for a sustainable forestry: avoidance of natural habitats loss, maintenance of ecological connectivity, maintenance of forest heterogeneity (diversity of species, ages and successional stages), focus of management onto the landscape scale, avoidance of forest-use intensification (Noss 2001; Lindenmayer et al. 2006; Brang et al. 2014).

\section{Methodology: Framing an interdisciplinary study case}

To evaluate on-the-ground adaptations, we carried out individual semi-structured and open-ended interviews in France during June and July 2017. Interviewees were private owners, officials from municipalities and central agencies, and forest managers.

Ecologists usually base their environmental analyses on the production and validation of logical knowledge (Moon and Blackman 2014). Yet, ecological consequences of ACC practices are due to human reasoning and motivations departing from objective mechanisms. Hence, a constructivist method fits with the objective of exploring how interviewees relate (or not) biodiversity conservation with ACC in forest management (Kaufmann 2004). Each interview consisted of i) a general description of the interviewee's silvicultural practices, ii) a description of the temporal evolution of these practices and iii) the interviewee's opinion about brakes and levers to reach desired silvicultural practices. If not spontaneously mentioned, we also asked what were their reactions following last decade's natural disturbances, for instance Lothar-Martin windstorms in 1999 or 2003 droughts (Ministère de la Transition écologique et solidaire 2017).

Every interview was recorded, fully transcribed and qualitatively analyzed. Audio tracks and written transcriptions were analyzed using Sonal, an encoder-software conducting audio-textual synchronization. Sonal allows for thematic and statistic discourse studies, such as topic occurrences and/or co-occurrences (e.g. "logging practices" and/or "forest uses") (Nicolas 2013). To be considered as an ACC, an interview sample should mention the expression of a change in forest management practices, either explicitly linked with climate change (ex: "first thing, forest stand management in the context of climate change"), or 
implicitly linked with at least one of climate change consequences (ex: mitigation policies and demand for non-fossil energy sources "we used to produce around 35,000 tons of fuelwood"). Once an interview sample was referenced as mentioning an ACC, it was characterized depending on adaptation category, interventionism level, motive, temporality, spatial scale of application, adaptation of what, adaptation to what. To avoid arbitrary classifications, characterizations were cross-checked by another author after being carried out by one author.

Adaptation category. Mentions of ACC were classified under the categories "Forestuse market diversification », «Insurances », «Land-use change », « Natural selection » (eg. forest stands with spontaneous evolution), «Research and development», «Silvicultural changes - forest density », «Silvicultural changes - pest control », « Silvicultural changes physical and chemical environment», "Silvicultural changes - quality management», «Silvicultural changes - rotation length », «Silvicultural changes - technical itinerary » (eg. Conversion of a regular woodland into an uneven-aged stand), «Silvicultural changes - tree species », «Social innovation» (modifications of social interactions, eg. creation of forest tales about climate change), «Timber market diversification » (eg. selling timber products as fuelwood, lumber, wood for paper fibres, ...).

Interventionism. Interventionism qualified whether adaptations could have occurred without human intervention. When applicable, assessment of whether the ACC 'would exist without human intervention', 'reversibility' and 'coercition of ecological dynamics" were based on interviews analyses and cited literature. An ACC was considered 'existing without human intervention' when it occurs in the wild (eg. species mixes), 'reversible' when the time needed to return to pre-adaptation conditions is lower or as long as the implementation time of the adaptation (eg. thinning is reversible, because it occurs every decade, long enough for forests to densify again). 'Coercition of ecological dynamics' qualified an ACC as going counter-current of the ecological dynamics ('Control and Command') or as accompanying ecological dynamics ('Monitor and Adapt'). For instance, if a local tree population declines because of rarefying rainfalls or increasing droughts, its maintenance through artificial plantations would correspond to 'Control and Command'. In this case, a 'Monitor and Adapt' envision of ecological dynamics could be funding research and development for adapting timber transformation machines to the tree species replacing the declining one.

Motive. Purposes of adaptations were assessed using a 'adapting for or by biodiversity' and a 'adapting for forests or for social-economic systems' criteria. Assessments stemmed from interviewees' expressed opinions.

Temporality. Reactive adaptations are "adjustments in ecological, social, or economic systems in response to observed or expected changes in climatic stimuli and their effects" (Adger et al. 2005). Hence, an ACC was counted as reactive when an interviewee implemented it to avoid detrimental impacts of a climatic risk already experienced (windstorm, fire, ...). Proactive adaptations are measures taken to lessen the perceived negative impacts of future events (Engle 2011). An ACC was therefore counted as anticipative when the interviewee mentioned it as an a priori preparation of predicted climate changes. When the action of ACC was first a by-product of another action, it was considered as « Side effect of other silvicultural changes » $(e g$. resulting from economic strategies, some shortened rotations also have interest for ACC).

Spatial scale of application. The scale of the ACC was always clearly apparent or explicit in the interviews. Spatial scales described the spatial extent of the ACC: the individual (ex: inclusion of silvicultural changes in popular culture), the forest stand, the municipality, the whole forest (massif) or the whole country (ex: observatory network of the effects of climate change on trees).

Adaptation of what. Discourse analysis gathered elements highlighting what ecosystem services were preferentially targeted by interviewees' ACC. 
Adaptation to what. Discourse analysis gathered elements highlighting what were the risks against which interviewees mentioned ACC. For instance, shortening rotation lengths was sometimes displayed as an ACC to drought, sometimes to windstorms.

As any methodology, ours has its own limitations. In several interviews, it was not possible to cross-check the interviewees' statement with field visits (interviews were nevertheless included in the study). Another limitation pertains to sampling biases: because interviewees are by definition foresters within reach of researchers, they are also involved in professional networks prone to release informations about ACC. This was taken into account in the analyses, but as this bias applies to every interviewees, it was not considered as questioning our results.

The selection of study areas was guided by social-ecological considerations so to retain two very contrasted forests characterizing polar opposites of French forest management (see Table 1). The first study area - the man-created forest of the "Landes de Gascogne" (hereafter refered to as "Landes") - lies in southwestern France and is grounded on a young and very interventionist history. The draining of former marshlands two centuries ago led to a mechanized and monocultural forestry. Soils are plowed to plant selected seedlings (Pinus pinaster) that are usually clearcut between their thirtieth and fortieth year. On the opposite, the second study area, known as the "Vosges du Nord" ("Vosges"), displays a silvicultural history that dates back over 400 years (Jéhin 2005): an important proportion of forests are composed of uneven-aged and mixed stands. These areas were also chosen on the basis of local natural parks managers showing interest in ACC studies linked with biodiversity issues. It must be kept in mind that our study areas are not representative of the whole French silvicultural technics range. Hence, our results must not be taken as applicable for the whole country : they reflect two distinct and strong opposites of how foresters deal with ecological processes in their silvicultures.

In that respect, forests can be studied as social-ecological systems (SES), for they couple Darwinian adaptation with socio-economic adaptations arising in interconnected demographic, cultural and economic contexts (Anderies et al. 2006). An interdisciplinary combination of geography and ecological sciences is therefore relevant to address the inclusion of biodiversity in foresters' ACC measures.

Table 1. Comparative description of the two study areas. Source of the map: www. http://www.parcs-naturels-regionaux.fr/.

\begin{tabular}{|c|c|c|}
\hline $\begin{array}{c}\text { Forest composition (proportion } \\
\text { of the park) }\end{array}$ & $\begin{array}{c}\text { Landes de Gascogne } \\
\text { Pinus pinaster (80\%), } \\
\text { Quercus robur (12\%) }\end{array}$ & $\begin{array}{c}\text { Fagus sylvatica, Pinus } \\
\text { sylvestris, Quercus sp. } \\
\text { (together 60\%) }\end{array}$ \\
\hline Private ownership & $95 \%$ & $15 \%$ \\
\hline Number of interviewees & 14 & 13 \\
\hline Vulnerability to climate change & $\begin{array}{c}\text { Droughts, fires, } \\
\text { windstorms, parasite risks }\end{array}$ & Droughts, windstorms \\
\hline Natural regional park & Yes & Yes \\
\hline
\end{tabular}




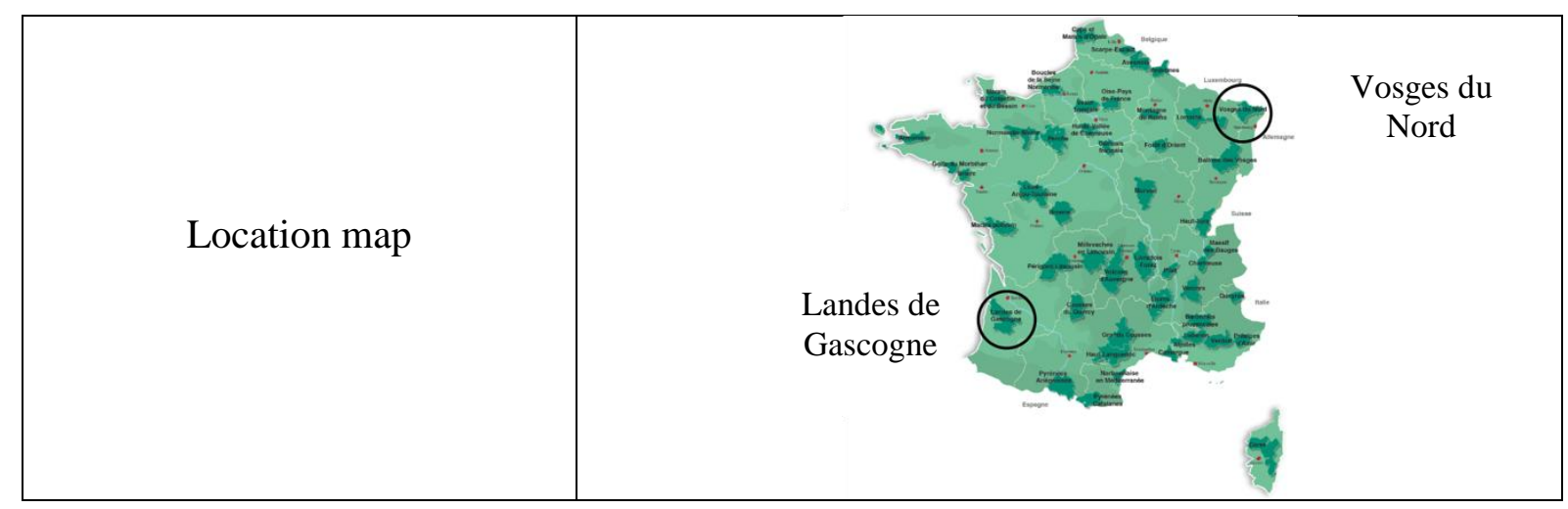

\section{Results}

97 mentions of ACC were compiled from a total of 27 interviews (13 in the Landes, 14 in the Vosges). Only one forester did not explicitly mention any ACC, but he insisted on his silvicultural practices being flexible to environmental and external changes. Interviews were usually 1 to 2 hours long, but could last up to 5 hours.

Adaptation category. Changing tree species (mixes, replacement, ...), acting on the physical and chemical environment (by subsoiling, fertilization, ...) and diversifying timber sales are the three most widespread mentions of ACC (Table 2). On the contrary, diversifying forest economic uses (tourism), innovating socially (development of forest tales related to climate changes) are the two least mentioned ACC (Table 2).

Interventionism. Interviewees predominantly mention interventionist ACC. 49 out of 97 ACC would not occur without human interventions (eg. shortened cutting age to avoid climate risks artificially modifies the age pyramid of forest stands) (Table 2). 8 out of 14 categories of ACC are not reversible. In terms of coercition of ecological dynamics, 63 ACC envision biodiversity in a 'Control and Command' way, going counter-current of the ecological dynamics occurring (eg. artificially maintaining a declining tree population by plantations).

Motive. Where applicable, a vast majority of the ACC consider biodiversity as a tool to adapt and not as an adaptation motive (57 ACC among the 97 are 'by diversity'), without exclusivity of the two approaches (11 ACC considered biodiversity both as a tool and an objective) (Table 2). 5 out 14 ACC categories aim at modifying forest ecosystems (change in the relative abundance of tree species or in the age and height structures of forest stands, etc.) and not at modifying social-economic systems (incentive to buy insurances against storms, cultural acceptance of free evolution, etc.) (Table 2).

Temporality. An ACC could be counted both as reactive and anticipative, because a given ACC can arise after a climatic hazard and also in prevention of upcoming climatic hazards. ACC are slightly more mentioned because of experienced climatic hazards than because of forecasted climate changes. However, among the climatic changes most feared in anticipation, drought already stroke the Landes and Vosges several times last decades (Table $3)$. Thus, ACC that were mentioned either in reaction or in anticipation to climatic risks essentially arise from past and experienced climatic hazards (Table 3).

Spatial scale of application. Adaptations largely apply at the forest stand scale (62 mentions out of 97) and at the forest scale (23 mentions). Noticeably, only one ACC concerned the individual scale: cultural heritage, in other words, the development of forest tales linked with climatic hazards (windstorms) (Table 4).

Adaptation of what. ACC first aim at adapting timber production (63 mentions out of the 97 mentioned ACC). There is only one instance of ACC of biodiversity for itself, while 
the other ACC aiming at adapting biodiversity are always related either to the adaptation of timber production or of aesthetic landscapes (7 mentions) (Table 4).

Adaptation to what. Top-mentioned ACC are mostly in responding to punctual and already experienced climatic risks: droughts (34 citations), windstorms (32 citations), demand for renewable and non-fossil energy (15 citations), parasitic attacks (12 citations) (Table 3 ).

\section{Discussion}

\section{Biodiversity conservation as an adaptation by-product of utilitarian timber production}

Contrasting with the often reported lack of ACC implementation (Campbell et al. 2008), almost all interviewees mentioned ongoing or operational adaptation measures - 97 in total (Table 2). This can be attributable to the long-term planning of forest management and to the strong forest cultures of the Landes and the Vosges. Following Carpenter (2001), two main questions can shape the study of how biodiversity issues are integrated among these 97 ACC. To what climatic risks are forest adapted? What are the forest goods and services targeted?

The first lesson from the field about to what foresters adapt is common: ACC were mostly in reaction to droughts and windstorms, two climatic hazards that occurred in both study areas (Table 3). For instance, Lothar-Martin windstorms in 1999 devastated more than $30 \%$ of the Landes stands and also hit the Vosges, as put simply by a forestry advisor: "When the wind is strong here, many people can't sleep anymore...". Reactive adaptations are rooted in the enhanced perception of risks already experienced, a cognitive bias found in other environments (Rey-Valette et al. 2012). Paradoxically, the third most mentioned ACC is not related to climate hazards but to an indirect consequence of mitigation policies. The mitigation-driven demand for renewable and non-fossil energy sources leads to increased fuelwood supply through slash and stump removal, seen as a business opportunity for wood producers.

Interviewees also detailed what forest services they try to adapt, and biodiversity conservation was clearly less cited as an adaptation target than timber production (by far the top-ranked one, Table 4). Moreover, biodiversity conservation was nearly systematically mentioned along with forest scenery or timber production (Table 4). This is not surprising, as timber production is the major source of income and concentrates adaptation efforts. To quote a forest manager, "Today, forest owners only earn money from timber sales, around $90 \%$ of their incomes, with lease of hunting being the other $10 \%$. The rest of it [biodiversity conservation and carbon sequestration] is a gift to the society, and we even pay property taxes for that!". Careful application of payment for ecosystem services could be an interesting way out of the predominance of timber production in ACC, with a collective share of biodiversity conservation costs (Farley and Costanza 2010).

This focus on timber production might explain why forest stand is the spatial scale referred to as the most efficient to achieve ACC (64\% of all ACC mentions). Timber production is indeed designed and managed at the forest stand level. This raises the issue of spatial integration of biodiversity dynamics, which do not stop at the forest stands limits. The ACC emphasis on forest stands could be a brake for managing ecological connectivity, one of the putative safeguards for biodiversity conservation being the key role played by natural parks authorities. Supporting this vision, it is almost only forest officials with responsibilities regarding biodiversity conservation who cited the whole forest as their ACC spatial scale the second most cited spatial scale (Table 4). As an example, Vosges park managers underlined the necessity to plan ACC at the forest scale because they must ensure ecological corridors. To rebalance the impacts of shortened rotations, they established a no-management 
network composed of old-growth patches. Authorities of deconcentrated services of the Ministry of Environment also expressed their full consideration of long-term changes (e.g. phenological or temperature shifts), even if ACC in anticipation were less implemented than reactive ACC. Concerns persist because authorities (whether from natural parks or from State services) must comply to national public policies that did not prove very pioneering regarding biodiversity conservation. For instance, it is only in 2017 that the national plan for adaptation to climate change incorporated recommendations for protected natural areas and biodiversity (Observatoire National des Effets du Réchauffement Climatique 2017).

Biodiversity conservation overwhelmed by an interventionist approach of adaptation to climate change

Interviewed foresters mostly considered biodiversity as a tool to adapt and not an adaptation goal in itself, as outlined in Table 2. However, a utilitarian approach of biodiversity does not necessarily imply an interventionist conception of ACC. Successful silvicultural attempts exist that balance long-term utilitarian cost-minimizing timber production with environmental imperatives (Brang et al. 2014). In France, the ProSilva organization promotes a close-to-nature forestry with mixed forests, heterogeneous structures, natural regeneration when possible and avoidance of clear cuts (de Turckheim and Bruciamacchie 2005; ProSilva 2017). Interviewed in the Vosges, a prominent member of ProSilva summarized his vision of biodiversity as an ACC tool: "Stability of production is important. So a diversified system is more stable, more perennial than a house of cards. Any grain of sand and everything collapses, then you're lost."

Still, most of the 97 collected ACC were interventionist, for instance excluding the social-economic system as the adaptation target to be modified in order to ensure ACC (Table 2). In other words, human intervention condition most of the reported ACC, such as planting trees according to windstorms tracks to decrease their wind surface areas. Human intervention is not always by essence detrimental to biodiversity, when it comes to conservation efforts even if they are most often designed to offset anthropogenic forcing. For some forest species, concerns exist about their ability to adapt fast enough (through Darwinian evolution, dispersion, range expansion or phenotypic plasticity) (Campbell et al. 2008). More specifically, trees have long generation time and some species have low ability to disperse (Corlett and Westcott 2013); issues of time lag between climatic changes and biological responses could make it relevant to plan human-based adaptation of such organisms (Millar et al. 2007). However, virtually none of the interviewees spontaneously came to that question.

Most of the mentioned ACC mentioned are irreversible and therefore very sensitive issues when dealing with species mixes and provenances. For instance, the intentional translocation of tree populations to account for climatic risks (assisted migration) can introduce unwanted genotypes in target environments (Millar et al. 2007; Lefèvre et al. 2014). Great care must be taken not to forget key ecological mechanisms, such as translocation of tree populations without considering their extended phenotype - their association with soil fungi or arthropods communities on source sites (Frascaria-Lacoste and Fernández-Manjarrés 2012). Most of species-based ACC mentioned were cautious in implementation, as for instance the migration of an oak population from southern France into the Vosges to address temperature shifts. Still, even if this pilot experiment did not foster non-native species introduction, careful monitoring is required to evaluate whether introduced trees outperform local populations or if they contribute to genetic mixing. French ACC public policies could be a way to implement precautionary measures with respect to sustainable forestry principles (Sansilvestri et al. 2015). 
Table 2. Classification of the 97 adaptations to climate change collected from French foresters, with their interventionism characteristics. Figures correspond to the number of occurrences of an adaptation category in the interviews. For instance, "insurances against climatic hazards" count for 2 adaptations out of the 97 identified in the interviews; in these cases, adaptations touch upon social-economic systems, they are reversible and in a 'Monitor and Adapt' vision of ACC.

\begin{tabular}{|c|c|c|c|c|c|c|c|c|c|c|c|c|c|c|c|}
\hline \multirow{2}{*}{ Adaptation category } & \multirow{2}{*}{$\begin{array}{l}\text { Number of } \\
\text { occurrences }\end{array}$} & \multirow{2}{*}{ Examples } & \multicolumn{4}{|c|}{$\begin{array}{l}\text { Adaptation for or by } \\
\text { biodiversity? }\end{array}$} & \multirow{2}{*}{$\begin{array}{l}\text { Adaptation of } \\
\text { forests or of } \\
\text { social- } \\
\text { economic } \\
\text { (human) } \\
\text { systems? }\end{array}$} & \multicolumn{4}{|c|}{$\begin{array}{l}\text { Would the adaptation exist } \\
\text { without human intervention? }\end{array}$} & \multirow{2}{*}{ Reversibility } & \multicolumn{3}{|c|}{$\begin{array}{c}\text { Coercition of ecological } \\
\text { dynamics }\end{array}$} \\
\hline & & & By & For & $\begin{array}{c}\text { For and } \\
\text { by }\end{array}$ & $N A$ & & Yes & No & $\begin{array}{l}\text { Maybe } \\
\text { but } \\
\text { slower }\end{array}$ & $N A$ & & $\begin{array}{l}\text { Control \& } \\
\text { Command }\end{array}$ & $\begin{array}{l}\text { Monitor } \\
\text { \& Adapt }\end{array}$ & $N A$ \\
\hline Insurances against climatic hazards & 2 & Insurances against windstorms & - & - & - & 2 & Humans & - & - & - & 2 & Yes & 0 & 2 & 0 \\
\hline Land-use change & 8 & $\begin{array}{l}\text { Switch to photovoltaic plants or } \\
\text { organic agriculture by land clearing }\end{array}$ & - & - & - & 8 & Forests & - & 8 & 0 & - & No & 8 & 0 & 0 \\
\hline Timber market diversification & 12 & $\begin{array}{l}\text { Sales diversification towards } \\
\text { fuelwood, introduction of contractual } \\
\text { sales of timber }\end{array}$ & 9 & 3 & 0 & - & Forests & - & - & - & 10 & Yes & 9 & 3 & 0 \\
\hline Forest-use market diversification & 1 & $\begin{array}{l}\text { Market diversification towards non- } \\
\text { timber forest products (mushrooms) } \\
\text { and recreational activities }\end{array}$ & 1 & 0 & 0 & - & Humans & 1 & 0 & 0 & - & Yes & 1 & 0 & 0 \\
\hline Research and development & 4 & $\begin{array}{c}\text { Establishment of regional } \\
\text { observatories of climate change }\end{array}$ & 1 & 3 & 0 & - & Humans & & 3 & 1 & 3 & Yes & 1 & 3 & 0 \\
\hline Natural selection & 9 & $\begin{array}{l}\text { Acceptance of spontaneous evolution } \\
\text { in forest stands }\end{array}$ & 2 & 3 & 4 & - & Humans & 9 & 0 & 0 & - & Yes & 0 & 9 & 0 \\
\hline Social innovation & 1 & $\begin{array}{l}\text { Storytelling of forest and climate } \\
\text { tales for children }\end{array}$ & - & - & - & 1 & Humans & 0 & 1 & 0 & - & Yes & 0 & 1 & 0 \\
\hline Silvicultural changes - forest density & 7 & Reduced forest density & 7 & 0 & 0 & - & Forests & 1 & 6 & 0 & - & No & 7 & 0 & 0 \\
\hline $\begin{array}{l}\text { Silvicultural changes - physical and } \\
\text { chemical environment }\end{array}$ & 12 & Subsoiling, soil tillage, fertilisation & 2 & 0 & 1 & 9 & Forests & 1 & 11 & 0 & - & No & 10 & 2 & 0 \\
\hline Silvicultural changes - tree species & 29 & $\begin{array}{c}\text { Species mixes, varietal selection, } \\
\text { assisted migration, species } \\
\text { replacement }\end{array}$ & 26 & 0 & 3 & - & Forests & 13 & 12 & 4 & - & No & 20 & 7 & 2 \\
\hline Silvicultural changes - technical itinerary & 3 & Close-to-nature forestry & 1 & 0 & 2 & - & Forests & 3 & 0 & 0 & - & Yes & 0 & 3 & 0 \\
\hline Silvicultural changes - pest control & 2 & Biocontrol using $B$. thuringiensis & 1 & 0 & 1 & - & Forests & 1 & 1 & 0 & - & No & 1 & 1 & 0 \\
\hline $\begin{array}{c}\text { Silvicultural changes - quality } \\
\text { management }\end{array}$ & 2 & Increased stand thinning & 2 & 0 & 0 & - & Forests & 0 & 2 & 0 & 1 & No & 1 & 1 & 0 \\
\hline Silvicultural changes - rotation length & 5 & Shortened rotations & 5 & 0 & 0 & - & Forests & 0 & 5 & 0 & - & Yes & 3 & 2 & 0 \\
\hline TOTAL & 97 & & 57 & 9 & 11 & 20 & & 29 & 49 & 5 & 16 & & 63 & 32 & 2 \\
\hline
\end{tabular}


Interventionism is also significantly rooted in the coercition of ecological dynamics, as suggested by the prevalence of 'Control and command' ACC (around 65\% of ACC). For these ACC, adaptation focuses on a single variable of the environment without integrating potential side-effects, often supported by a technological framing of the response to a climatic hazard. An archetypal example is provided by some Landes forest owners, who aim at extending soil root exploration on their forest stands. Before planting, some of them used 250 horse-power subsoilers to break the hardest horizon of the soil. However, they sometimes reported maladaptation to droughts, for subsoiling increased water draining and lowered water soil retention. Moreover, their stand were less resilient to windstorms, because maritime pines would break in two instead of falling untouched on the floor as a consequence of their deeper root anchorage. This 'Control and command' ACC was only focusing on adaptation to droughts and hindered access to forest stands and harvest of damaged trees, disregarding forest complexity.

Table 3. Adaptation to what? Reasons of silvicultural changes mentioned by interviewees, classified by reaction or anticipation. Figures correspond to the number of occurrences of an adaptation category in the interviews. (Because a silvicultural change can arise from different reasons, some ACC were counted twice, hence totals are superior to 97.) For instance, 12 adaptations were mentioned as dealing with parasite attacks, among which 4 followed a parasite attack and 8 anticipate parasite attacks.

\begin{tabular}{c||c|c|c|c|c} 
Silvicultural changes driven by ... & $\begin{array}{c}\text { In reaction to a } \\
\text { past climatic } \\
\text { event }\end{array}$ & $\begin{array}{c}\text { In anticipation to } \\
\text { forecoming climatic } \\
\text { events }\end{array}$ & $\begin{array}{c}\text { Change first mentioned as an } \\
\text { adaptive side effect of other } \\
\text { silvicultural evolution unrelated } \\
\text { to climatic hazards }\end{array}$ & $\begin{array}{c}\text { Reaction or } \\
\text { anticipation } \\
\text { not specified }\end{array}$ & TOTAL \\
\hline $\begin{array}{c}\text { Demand for renewable and non- } \\
\text { fossil energy } \\
\text { Frosts }\end{array}$ & 15 & - & - & - & 15 \\
Hailstorms & 3 & 1 & - & - & 4 \\
Fires & - & 1 & - & - & 1 \\
Windstorms & 4 & 3 & - & - & 7 \\
Droughts & 24 & 6 & 2 & - & 32 \\
Parasite attacks & 6 & 22 & 4 & 2 & 34 \\
NA & 4 & 8 & - & - & 12 \\
Changes in rainfall patterns & - & 10 & - & 1 & 7 \\
Wildlife browsing & - & 4 & - & - & 1 \\
Demand for carbone capture and & - & 1 & - & - & 1 \\
storage & - & - & - & - & 9 \\
Mix of at least two of the climate \\
changes
\end{tabular}

In the end, the interviews allow to examine the impacts of ACC choices on biodiversity through the prism of the sustainable forest principles:

- Avoidance of natural habitat loss could suffer from shortened rotations, as fewer old trees hosting cavities would stay in forests after logging (Fan et al. 2004; Lindenmayer et al. 2006). In the Vosges, attention has been focused on the loss of cavity trees, and a compensatory network of old-growth trees has been implemented for thirty years.

- Maintenance of ecological connectivity and focus on the landscape scale is of greater concern, as the most quoted spatial scale was the forest stand (see section 1) 
- Maintenance of forest heterogeneity (diversity of species, ages and successional stages) first depends on owners' silvicultural practices. In public forests, the multifunctionality injunction imposes to take biodiversity into account, but on-theground implementation is at the discretion of local managers. In the Landes forests, owners are mainly individuals who pay a tax dedicated to fire prevention, a brake for fire-based heterogeneity of forests but a prerequisite for timber production (Doustin 1975). Forestry goals and local contexts therefore greatly condition the forest heterogeneity management principle, with consideration through ongoing research about tree diversity and herbivory by forest insects (Jactel and Brockerhoff 2007).

- Avoidance of forest-use intensification might be the biggest focus point when it comes to adaptation to the indirect effects of climate change. Economic adaptation to the rise in fuelwood demand, indirectly due to mitigation policies, could lead to extended harvest of slash and stump, threatening long-term soil equilibrium (Jandl et al. 2007; Walmsley and Godbold 2010). Inertia of private owners could nevertheless balance intensification of forest-use, as shown by several interviews: numerous forest owners cannot afford investments in forest roads or have too small forest holdings to derive benefits from fuelwood sales.

Table 4. Adaptation of what ecosystem services, on what spatial scales? Forest services mentioned as the interviewees' focus for ACC, classified by spatial scale. Figures correspond to the number of occurrences of an adaptation category in the interviews. Ex: among the 4 ACC aiming at adapting timber production and biodiversity, 2 were designed at the forest stand level and 2 at the forest massif scale.

\begin{tabular}{|c|c|c|c|c|c|c|}
\hline \multirow{2}{*}{$\begin{array}{l}\text { Forest use or ecosystem service to be } \\
\text { adapted }\end{array}$} & \multirow{2}{*}{$\begin{array}{l}\text { Total number of } \\
\text { occurrences }\end{array}$} & \multicolumn{5}{|c|}{ Spatial scale } \\
\hline & & Individual & Forest stand & Municipality & Forest massif & Country \\
\hline Timber production & 63 & - & 45 & - & 16 & 2 \\
\hline $\begin{array}{c}\text { Not applicable (NA) / Undefined by } \\
\text { interviewee }\end{array}$ & 14 & - & 8 & - & 5 & 1 \\
\hline Land use & 8 & - & 4 & 4 & - & - \\
\hline Timber production and biodiversity & 4 & - & 2 & - & 2 & - \\
\hline $\begin{array}{l}\text { Timber production, biodiversity and } \\
\text { esthaetic landscape }\end{array}$ & 3 & - & 2 & - & 1 & - \\
\hline Recreational activities & 1 & - & 1 & - & - & - \\
\hline Biodiversity conservation & 1 & - & - & - & 1 & - \\
\hline Soil retention to prevent erosion & 1 & - & - & 1 & - & - \\
\hline Cultural heritage (forest history) & 1 & 1 & - & - & - & - \\
\hline Human health & 1 & - & - & - & 1 & - \\
\hline TOTAL & 97 & 1 & 62 & 5 & 26 & 3 \\
\hline
\end{tabular}

\section{Conclusions}

In order to assess potential long-term adverse effects of ACC on biodiversity conservation, we interviewed foresters, forest authorities and forest owners. Two forest cases contrasting in anthropization were selected: the "Landes de Gascogne" and the "Vosges du Nord", both 
study areas complying with France's forest specificities: vast, multifunctional, and managed (at least public forests). Analyses of the collected mentions of ACC were conducted in the light of sustainable forestry principles: avoidance of natural habitats loss, maintenance of ecological connectivity, maintenance of forest heterogeneity, focus onto the landscape scale, avoidance of forest-use intensification (Noss 2001; Lindenmayer et al. 2006; Brang et al. 2014).

Much of ACC mentioned were utilitarian - considering biodiversity as a tool to adapt and not as a conservation goal. Much of them were also interventionist, designed to adapt forest environments to timber production, most often without questioning the adaptation of human social-economic systems. Based on the interviews, integrating biodiversity conservation within this interventionist context seems highly relevant, since timber production should probably persist as one of forest most used ecosystemic services, a consideration found across other research projects (O'Hara and Ramage 2013). Still, numerous difficulties persist to evaluate the impacts on biodiversity of ACC of forestry practices. Are interventionist ACC required for biodiversity conservation, or can forest environments adapt to climate change without human interventions? In a few cases, such as shortened rotations or subsoiling, effects on biodiversity of interventionist ACC are quite straightforward to measure. But interventionism is not always so unequivocal, due to numerous ecological and climatic uncertainties (Campbell et al. 2008). An example is assisted migration, where uncertainties are high about the tree real velocity, dispersal, acclimation to phenological shifts or about gene flow from supposed adapted populations, not to mention the variety of ecological processes harsh to evaluate (Frascaria-Lacoste and Fernández-Manjarrés 2012; Corlett and Westcott 2013).

Favoring intervention or spontaneous evolution is of no little importance, but uncertainty renders it difficult to follow accurate guidelines (Hallegatte 2009). When considering the implementation of an ACC, we first recommend end-users to base their practical decision-making on sustainable forestry principles. When applicable, we also suggest to include uncertainty in their everyday silvicultural practices by systematically preferring the one option with positive outcomes over a wide range of futures, in order to avoid "putting all eggs into one basket" (Dessai et al. 2009; O'Hara and Ramage 2013).

These silvicultural practices impacting forest environments are based on social and economic decision-making. Thus, interdisciplinary research is critical to long-term successful biodiversity conservation. Understanding adaptation processes is one thing, but basing nature parks management on recent knowledge is another. From a conservationist point of view, ACC for biodiversity conservation is a challenge that requires maintained and enhanced exchanges between researchers from different fields and nature parks managers (Stein et al. 2013). Learning from literature study cases and formal and informal professional meetings stays indispensable to encourage capacity-building and adoption of the 'Monitor and adapt' management paradigm. In this logic, reversibility of ACC and ecological threshold uncertainties - genetic bottlenecks, effects of thinning or slash removal on ecosystem functioning, ... - are to be monitored. 'Monitor and adapt' could also participate in integrating laisser-faire measures as a pro-active choice within the ACC range.

Considering that forest officials are those accounting the most for biodiversity, it would also be legitimate to question whether their interactions with forest owners or forest experts leads to better integration of these forest sustainability principles. Methodological constraints do not allow us to go beyond the one-to-one interviews, but another research project is in progress. Based on companion modelling and serious games (Bousquet and Le Page 2004; Etienne and ComMod 2015), it aims at analyzing the importance of communication between forest stakeholders for incorporating biodiversity conservation in the players' ACC strategies. 
Explicitation of how foresters first consider biodiversity as a utilitarian tool to maintain productive forests could be our main result for biodiversity conservation. This could be a significant asset for biodiversity conservation in non-protected forests. Indeed, clarifying the value of biodiversity for ACC is a first stage to rise awareness about conservation importance - so long as the utilitarian perception of biodiversity is not the only one. In this light, the emergence of public policies relying on ecosystem-based adaptation and on naturebased solutions is a step in this direction (Balian et al. 2014; Eggermont et al. 2015). Aiming at turning adaptation with nature into something as efficient as adaptation against nature, this promising concept could become in the coming years a useful communication tool reconciling biodiversity conservation with other ecosystemic services in multifunctional environments. In 2018, renewal in France of both the national plan for adaptation to climate change and the national mitigation strategy will be chances to assess the inclusion of nature-based solutions in public policies for biodiversity conservation.

\section{References}

Adger WN, Arnell NW, Tompkins EL (2005) Successful adaptation to climate change across scales. Glob Environ Change 15:77-86 . doi: 10.1016/j.gloenvcha.2004.12.005

Anderies J, Walker B, Kinzig A (2006) Fifteen weddings and a funeral: case studies and resilience-based management. Ecol Soc 11:

Balian E, Eggermont H, le Roux X (2014) Outputs of the Strategic Foresight workshop "Nature-Based Solutions in a BiodivERsA context". BiodivERsA, Brussels

Barthod C (2015) La multifonctionnalité des forêts entre discours et pratiques : illusion ou réalité à assumer? Rev For Fr

Bousquet F, Le Page C (2004) Multi-agent simulations and ecosystem management: a review. Ecol Model 176:313-332 . doi: 10.1016/j.ecolmodel.2004.01.011

Brang P, Spathelf P, Larsen JB, Bauhus J, Bonc ina A, Chauvin C, Drossler L, GarciaGuemes C, Heiri C, Kerr G, Lexer MJ, Mason B, Mohren F, Muhlethaler U, Nocentini S, Svoboda M (2014) Suitability of close-to-nature silviculture for adapting temperate European forests to climate change. Forestry 87:492-503 . doi: 10.1093/forestry/cpu018

Campbell A, Kapos V, Chenery A, Kahn S, Rashid M, Scharlemann JPW, Dickson B (2008) The linkages between biodiversity and climate change adaptation. UNEP World Conserv Monit Cent

Carpenter S, Walker B, Anderies JM, Abel N (2001) From Metaphor to Measurement: Resilience of What to What? Ecosystems 4:765-781 . doi: 10.1007/s10021-001-0045-9

Corlett RT, Westcott DA (2013) Will plant movements keep up with climate change? Trends Ecol Evol 28:482-488 . doi: 10.1016/j.tree.2013.04.003

Dessai S, Hulme M, Lempert R, Pielke R (2009) Do we need better predictions to adapt to a changing climate? Eos Trans Am Geophys Union 90:111-112

de Turckheim B, Bruciamacchie M (2005) La futaie irrégulière - Théorie et pratique de la sylviculture irrégulière, continue et proche de la nature, Edisud. Saint-Remy-de-Provence

Doustin D (1975) Organisation de la lutte dans le massif landais. Rev For Fr 1975 Fasc Thématique Incendie For 500-503

Eggermont H, Balian E, Azevedo JMN, Beumer V, Brodin T, Claudet J, Fady B, Grube M, Keune H, Lamarque P, Reuter K, Smith M, van Ham C, Weisser WW, Le Roux X (2015) Nature-based Solutions: New Influence for Environmental Management and Research in Europe. GAIA - Ecol Perspect Sci Soc 24:243-248 . doi: 10.14512/gaia.24.4.9

Engle NL (2011) Adaptive capacity and its assessment. Glob Environ Change 21:647-656 . doi: 10.1016/j.gloenvcha.2011.01.019 
Etienne M, ComMod (2015) La modélisation d'accompagnement: partager des représentations, simuler des dynamiques. INRA, Paris

Fan Z, Shifley SR, Thompson FR, Larsen DR (2004) Simulated cavity tree dynamics under alternative timber harvest regimes. For Ecol Manag 193:399-412 . doi: 10.1016/j.foreco.2004.02.008

Farley J, Costanza R (2010) Payments for ecosystem services: From local to global. Ecol Econ 69:2060-2068 . doi: 10.1016/j.ecolecon.2010.06.010

Frascaria-Lacoste N, Fernández-Manjarrés J (2012) Assisted Colonization of Foundation Species: Lack of Consideration of the Extended Phenotype Concept-Response to Kreyling et al. (2011). Restor Ecol 20:296-298 . doi: 10.1111/j.1526-100X.2012.00875.x

Hallegatte S (2009) Strategies to adapt to an uncertain climate change. Glob Environ Change 19:240-247 . doi: 10.1016/j.gloenvcha.2008.12.003

Jactel H, Brockerhoff EG (2007) Tree diversity reduces herbivory by forest insects. Ecol Lett 10:835-848 . doi: 10.1111/j.1461-0248.2007.01073.x

Jandl R, Lindner M, Vesterdal L, Bauwens B, Baritz R, Hagedorn F, Johnson DW, Minkkinen K, Byrne KA (2007) How strongly can forest management influence soil carbon sequestration? Geoderma 137:253-268 . doi: 10.1016/j.geoderma.2006.09.003

Jéhin P (2005) Les forêts des Vosges du nord du Moyen-Age à la Révolution. Presses Universitaires De Strasbourg, Strasbourg

Juhola S, Glaas E, Linnér B-O, Neset T-S (2016) Redefining maladaptation. Environ Sci Policy 55:135-140 . doi: 10.1016/j.envsci.2015.09.014

Kaufmann J-C (2004) L'entretien compréhensif, Third edition. Armand Colin, Paris

Lefèvre F, Boivin T, Bontemps A, Courbet F, Davi H, Durand-Gillmann M, Fady B, Gauzere J, Gidoin C, Karam M-J, Lalagüe H, Oddou-Muratorio S, Pichot C (2014) Considering evolutionary processes in adaptive forestry. Ann For Sci 71:723-739 . doi: 10.1007/s13595013-0272-1

Lindenmayer DB, Franklin JF, Fischer J (2006) General management principles and a checklist of strategies to guide forest biodiversity conservation. Biol Conserv 131:433-445 . doi: 10.1016/j.biocon.2006.02.019

MAAF (2017) Programme National de la Forêt et du Bois 2016-2026. Ministère de l'Agriculture, de l'Agroalimentaire et de la Forêt, Paris

Millar CI, Stephenson NL, Stephens SL (2007) Climate change and forests of the future: managing in the face of uncertainty. Ecol Appl 17:2145-2151

Ministère de la Transition écologique et solidaire (2017) Géorisques | Mieux connaître les risques sur le territoire. http://www.georisques.gouv.fr/. Accessed 18 Dec 2017

Moon K, Blackman D (2014) A Guide to Understanding Social Science Research for Natural Scientists: Social Science for Natural Scientists. Conserv Biol 28:1167-1177 . doi: 10.1111/cobi.12326

Nicolas L (2013) Encodage et analyse de données qualitatives - Apports et limites du logiciel Sonal comme outil de recherche en SHS. Adjectif.net

Noss RF (2001) Beyond Kyoto: forest management in a time of rapid climate change. Conserv Biol 15:578-590

Observatoire National des Effets du Réchauffement Climatique (2017) Recommandations pour un nouveau Plan national d'adaptation au changement climatique. Observatoire National des Effets du Réchauffement Climatique, Paris

O'Hara KL, Ramage BS (2013) Silviculture in an uncertain world: utilizing multi-aged management systems to integrate disturbance. Forestry 86:401-410 . doi: 10.1093/forestry/cpt012

ProSilva (2017) Pro Silva France. https://www.prosilva.fr/html/index.html. Accessed 19 Dec 2017 
Rey-Valette H, Rulleau B, Meur-Férec C, Flanquart H, Hellequin A-P, Sourisseau E (2012) Les plages du littoral languedocien face au risque de submersion: définir des politiques de gestion tenant compte de la perception des usagers. Géographie Économie Société 14:369391. doi: 10.3166/ges.14.369-391

Sansilvestri R, Frascaria-Lacoste N, Fernández-Manjarrés JF (2015) Reconstructing a deconstructed concept: Policy tools for implementing assisted migration for species and ecosystem management. Environ Sci Policy 51:192-201 . doi: 10.1016/j.envsci.2015.04.005

Stein BA, Staudt A, Cross MS, Dubois NS, Enquist C, Griffis R, Hansen LJ, Hellmann JJ, Lawler JJ, Nelson EJ, Pairis A (2013) Preparing for and managing change: climate adaptation for biodiversity and ecosystems. Front Ecol Environ 11:502-510 . doi: 10.1890/120277

Walmsley JD, Godbold DL (2010) Stump Harvesting for Bioenergy - A Review of the Environmental Impacts. Forestry 83:17-38 . doi: 10.1093/forestry/cpp028 